bird, the Yellow Rail. And may that somebody have the time, the patience, and what I did not have the finances.

Editor's Note: The Museum has records of two specimens in addition to the one received from $R$. D. Symons. One, taken at the north end of Last Mountain Lake in 1932 by Bert Lloyd, went to the Carnegie Museum, Pittsburg. The other, received from Ronald Hooper of Somme, July 13, 1954, is in the Museum at Regina. This specimen was one of two birds taken by the Hoopers in a large marsh at the confluence of the Bowman and Shand Creeks, where they flushed Yellow Rails on. June 8 (3) and June 10 $(12+)$. The stomach of one rail contained the remains of several beetles (one apparently belonging entirely to the Byrrhidae); the other, two small snails, two predacious diving beetle larvae (Water Tigers), and three small seeds. Another report of the occurrence of the Yellow Rail comes from E. M. Callin who has records of them heard (not seen) in the marsh at El Capo Lake and again at Round Lake.

\section{News from the REGINA NATURAL HISTORY SOCIETY}

By MARIE ROBINSON, secretary

Signed, sealed and delivered! Yes, at last the Regina Natural History Society has title to the property on which, ten years ago, they began the creation of a wild life sanctuary. This is a long-time dream come true and there are many exciting plans in the offing for the development of our "Hidden Valley" sanctuary.

A big event in our 1955-56 seasnn was the presentation of life memberships to Mrs. Betty Flock and $\mathrm{Mr}$. Jack Taylor. Both Betty and Jack were original members when the society was founded and have been very active, inspiring workers ever since.

We are happy to announce that the "World Wandering" nature shows being sponsored by our society are a huge success. These shows, which are open to the general public, are being featured in the Museum auditorium every Sunday during the win- ter months. Owing to the crowds that were being turned away every Sunday afternoon, we now have two shows, one at 3:30 p.m. and one at 8:30 p.m. Our president, Mr. Frank Brazier, deserves a great deal of credit for the effort he put forth in obtaining and assembling such outstanding, facinating, educational films. The Saskatchewan Museum of Natural History has also been most cooperative in this endeavor and we hope that, owing to this series of shows, many people will have become better acquainted with their new museum and will also have acquired a keener appreciation of the wonderful world we live in.

\section{SASKATOON NATURAL HISTORY SOCIETY}

\author{
MRS. J. GERRARD
}

The first general meeting of the newly-formed Saskatoon Natural History Society was held in the Physics building, University of Saskatchewan, January 26, with more than 60 people present. The guest speaker was Dr. R. W. Nero, Assistant Director of the Saskatchewan Museum of Natural History, who spoke on Bird Behaviour with particular reference to a colony of Red-winged Blackbirds.

The Executive Committee of the Society consists of: President, Dr. R. M. Bremner; Vice-president, Frank Roy; Recording and Corresponding Secretary, Mrs. John Gerrard; Membership Secretary and Treasurer, Glen Burgess; ex-officio Directors, Dave Robinson, Dr. L. G. Saunders, Dr. S. Houston:

The annual membership fee is $\$ 1.50$ which includes a compulsory subscription to The Blue Jay. The fee for family membership is $\$ 2.00$. If anyone would like to join the society Glen Burgess, 43 Community Apartments, Saskatoon, will be glad to receive subscriptions.

Raven's nest south of the Churchill River. - Mr. Czartoryski of Regina reported to the Museum on November 28, 1955 the finding of a Raven's nest in a ravine off a small lake, south of the Churchill River, in the early summer of 1955, by Emal Wurzycki, a La Ronge prospector. The nest was on a rocky ledge. 